\title{
IMPACT ON HEALTH EDUCATION FROM COVID-19 AND CLIMATE CHANGE
}

\author{
César Agostinis-Sobrinho, Inga Dailidienè, Alona Rauckienè-Michaelsson \\ Klaipeda University, Lithuania
}

\begin{abstract}
World Health Organization (WHO) health policy for Europe "Health 2020" became a stimulus for many countries to renew their national health policies, and it is a guide of actions (WHO, 2013). Long-term studies proved that health is closely linked to socio - economic indicators, among which age plays a major role, and education. Given that there are as many healthy people as possible, it is especially important to form the most important young people attitude to health, to develop a personality who would take care of the health of yourself, your family and those around you. Schools, colleges, and universities are the medium in which a mature generation of future intellectuals are capable and possessed to have a major influence on the development of the state and, with knowledge of the principles of good health, to contribute to and to shape the health policy of the right country, its implementation and at the same time to the population of the country improving health (Misevičiene et al., 2017).
\end{abstract}

\section{Active Lifestyle Behavior for Mental and Biological Health. The Student's Greatest Academic Challenge during the} COVID-19 Pandemic

The COVID-19 pandemic means that many people are staying at home (much in severe confinement) and doing less in terms of social interactions and physical activity. This can have a negative effect on your physical and mental health (Singh et al., 2020). In particular, millions of European adolescents are home schooling, yet there is little knowledge of how academic workload, separation from school, and fears of contagion lead to a decrease in their health (Singh et al., 2020). Last year the World health Organization presented study results from more than 227,000 schoolchildren "spotlight on adolescent health and well-being"(WHO, 2020). The data from 2017/2018 showed that mental well-being declined in many countries across Europe between 2014 and 2018 (WHO, 2020). One in four adolescents, for instance, report feeling nervous, feeling irritable or having difficulties getting to sleep at least once per week. Notably, data from Baltic States have presented great concern. Schoolchildren from Latvia have rated their health as the worst score between the 45 countries studied. Estonia and Latvia also are between the 5 countries who reported sleep difficulties and feeling dizzy more than once a week. Lithuania presented the greatest score on alcohol consumption and smoke. And the three Baltic state countries presented the first three positions on bullying complaints (WHO, 2020).

These results are even more frightening when we observe that they were collected before the COVID pandemic and the severe Lockdown. Several studies from our group (Agostinis-Sobrinho et al., 2019; Cesar Agostinis-Sobrinho et al., 2020; César Agostinis-Sobrinho et al., 2021) as well as others (Prieto-Benavides et al., 2019; Ramírez-vélez et al., 2016) have reported that active lifestyle behavior plays a key role on students' health, inappropriate levels of 
sleep, physical activity and sedentary behavior that are important risk factors for many non-communicable diseases. Taking all this into account, studies that generate new knowledge and the current state of health of children and adolescents in the current context of the COVID-19 pandemic, are extremely important.

\section{Climate Change and its Interactions with Ecosystems, People, Health and Educations}

Climate change issues are of major importance in the modern world and these problems have to be monitored and examined on the national level involving national organizations, business, and industry, research institutions, including the different education levels (Dailidienè et al., 2019). As stated in a public report by the World Bank (2013), a great many record-breaking heat events, heavy floods, and extreme droughts will occur if global warming crosses the $4^{\circ} \mathrm{C}$ level with respect to the pre-industrial period, which would cause severe threats to ecosystems, human systems, and associated societies and economies (Wang et al., 2018). Recent climate changes have had widespread impacts on human and natural systems (IPCC, 2014). It is also increasing human impacts on climate change. Recent anthropogenic emissions of greenhouse gases are the highest in history (IPCC, 2014). Climate change is a significant threat to the health of the people.

Climate change is already having an impact on health, with an increase in heat-related deaths in some regions and a decrease in cold-related deaths in others (Sarofim et al., 2016). World Health Organization noted that between 2030 and 2050, climate change is expected to cause approximately 250000 additional deaths per year, from malnutrition, malaria, diarrhea, and heat stress. Changes in climate are likely to lengthen the transmission seasons of important vector-borne diseases and to alter their geographic range. Areas with weak health infrastructure - mostly in developing countries - will be the least able to cope without assistance to adapt and respond to climate change.

Supporting the implementation of the public health response to climate change is linked to education. Now is the time for universities to become global leaders in the fight against climate change, not only for reasons of efficiency and economics, but also to avoid inflicting environmental degradation and the resultant deterioration of quality of life and human health, with a commitment to educating humanity at all levels of education, helping to mitigate the effects of future adaptation.

\section{References}

Agostinis-Sobrinho, C., Gómez-Martínez, S., Nova, E., Hernandez, A., Labayen, I., Kafatos, A., Gottand, F., Molnár, D., Ferrari, M., Moreno, L. A., González-Gross, M., Michels, N., Ruperez, A., Ruiz, J. R., \& Marcos, A. (2019). Lifestyle patterns and endocrine, metabolic, and immunological biomarkers in European adolescents: The HELENA study. Pediatric Diabetes, 20(1), 23-31. https://doi.org/10.1111/pedi.12802

Agostinis-Sobrinho, Cesar, Rosário, R., Santos, R., Norkiene, S., Mota, J., Rauckienè-Michaelsson, A., González-Ruíz, K., Izquierdo, M., Garcia-Hermoso, A., \& Ramírez-Vélez, R. (2020). Higher cardiorespiratory fitness levels may attenuate the detrimental association between weight status, metabolic phenotype and C-reactive protein in adolescents - A multi-cohort study. Nutrients, 12(5), Article 1461. https://doi.org/10.3390/nu12051461

Agostinis-Sobrinho, César, Werneck, A. de O., Kievišienè, J., Moreira, C., Ramírez-Vélez, R., Rosário, R., Norkiene, S., Lopes, L., Mota, J., \& Santos, R. (2021). Ideal cardiovascular health status and health-related quality of life in adolescents: The labmed physical activity study. Revista Paulista de Pediatria, 39, Article e2019343. https://doi.org/10.1590/1984-0462/2021/39/2019343

Dailidienè, I., Melnikova, J., Dabulevičienè, T., Dailidè, R., Razbadauskaitè-Venskè, I., \& Simanavičiūtè, G. (2019). Integration of climate change and adaptation management into learning curriculum in higher education. Vadyba/Journal of Management, $35(2), 161-167$

IPCC. (2014). Climate change 2014: Synthesis report. In Contribution of working groups I, II and III to the fifth assessment report of the intergovernmental panel on climate change (Vol. 27). IPCC Geneva, Switzerland.

Misevičienè, I., Špečkauskienè, V., \& RauckienèMichaelsson, A. (2017). Development of Health 2020 policy:Youth health. Visuomenes sveikata / Public Health, 1(76), 51-60. https://www.Ismuni.It/cris/handle/20.500.12512/18550

Prieto-Benavides, D. H., García-Hermoso, A., Izquierdo, M., Alonso-Martínez, A. M., Agostinis-Sobrinho, C., Correa-Bautista, J. E., \& Ramírez-Vélez, R. (2019). Cardiorespiratory fitness cut-points are related to body adiposity parameters in Latin American adolescents. Medicina (Kaunas, Lithuania), 55(9), Article 508. https://doi.org/10.3390/medicina55090508

Ramírez-Vélez, R., Tordecilla-Sanders, A., Correa-Bautista, J. E., Peterson, M. D., \& Garcia-Hermoso, A. (2016). Handgrip strength and ideal cardiovascular health among Colombian children and adolescents. The Journal of Pediatrics, 179, 82-89.e1. https://doi.org/10.1016/j.jpeds.2016.08.099

Sarofim, M. C., Saha, S., Hawkins, M. D., Mills, D. M., Hess, J., Horton, R., Kinney, P., Schwartz, J., \& Juliana, A. S. (2016). Ch. 2: Temperature-related death and illness. US Global Change Research Program.

Singh, S., Roy, M. D., Sinha, C. P. T. M. K., Parveen, C. P. T. M. S., Sharma, C. P. T. G., \& Joshi, C. P. T. G. (2020). Impact of COVID-19 and lockdown on mental health of children and adolescents: A narrative review with recommendations. Psychiatry Research, 293, Article 113429. https://dx.doi.org/10.1016\%2Fj.psychres.2020.113429 
Wang, X., Jiang, D., \& Lang, X. (2018). Climate change of 4 C global warming above pre-industrial levels. Advances in Atmospheric Sciences, 35(7), 757-770. https://doi.org/10.1007/s00376-018-7160-4

WHO. (2013). Health 2020: a European policy framework and strategy for the 21st century. World Health Organization. Regional Office for Europe.

WHO. (2020). Spotlight on adolescent health and well-being. Findings from the 2017. World Health Organization. Regional Office for Europe.

World Bank Report (2013). Turn Down the Heat. Climate Extremes, Regional Impacts, and the Case for Resilience. Report for Bank by the Potsdam Institute for Climate Impact Research and Climate Analytics. 254. The World Bank.

Cite as: Agostinis-Sobrinho, C., Dailidienè, I., \& Rauckienè-Michaelsson, A. (2021). Impact on health education from Covid-19 and climate change. Journal of Baltic Science Education, 20(2), 168-170. https://doi.org/10.33225/jbse/21.20.168

César Agostinis-Sobrinho

Inga Dailidiené

Alona Rauckienè-Michaelsson (Corresponding author)
PhD, Chief Researcher, Klaipeda University, Health Research and Innovation Science Centre, Klaipeda University, 84 Herkaus Manto Street, LT-92294 Klaipeda, Lithuania.

E-mail: cesaragostinis@hotmail.com ORCID: https://orcid.org/0000-0001-9104-9042

PhD, Professor, Klaipeda University, Health Research and Innovation Science Centre, Marine Research Institute, 84 Herkaus Manto Street, LT-92294, Klaipeda, Lithuania.

E-mail: inga.dailidiene@ku.lt ORCID: https://orcid.org/0000-0001-7919-6090

PhD, Associate Professor, Klaipeda University, Health Research and Innovation Science Centre, 84 Herkaus Manto Street, LT92294 Klaipèda, Lithuania.

E-mail: alona.rauckiene-michaelsson@ku.It ORCID: https://orcid.org/0000-0003-0337-8335 